\title{
MICE's Human Resources Development Strategy in Increasing the Competitiveness of the Event Organizer in South Sulawesi
}

\author{
Dharma Kuba ${ }^{1}$, Fuad Guntara ${ }^{2}$ \\ ${ }^{1}$ Politeknik Pariwisata Makassar, ${ }^{2}$ Institut Agama Islam Parepare \\ Email:padhaku@poltekparmakassar.ac.id
}

\begin{abstract}
Tourism in the MICE sector is one of the fields that increases the income of the tourism sector. Business visitor/MICE expenditure in Thailand 3.5 times leisure visitor. This study aims to determine the quality and strategy of human resource development for the MICE Event Organizer in South Sulawesi. This research uses a qualitative descriptive approach. There were four informants in the study. Data collection techniques used were observation, interviews, and documentation. Data analysis techniques, namely data classified and analyzed with theories related to the object of research. The results of the research are the quality of MICE Human Resources at the Event Organizer in South Sulawesi Selatan is quite good and the MICE Event Organize HR Development Strategy in South Sulawesi, namely 3 main strategies, namely development through internships and guidance, development through education and training and career development.
\end{abstract}

Keywords: MICE, HR quality, HR development strategy

\section{INTRODUCTION}

Revenue from the tourism sector in 2016 soared to become the second contributor of USD 13.5 million after palm oil (Kompas.com). Tourism in Indonesia is a sector that has great potential to support the country's economy (Kadji, 2015; Winowatan, 2019). Various tourist sites with various cultures are found throughout the archipelago, which is very possible and attracts the attention of visitors, both local and foreign tourists. This has become a strength for tourism development in Indonesia to date (Hasyim et al., 2020; Muhtasom \& Ab, 2019; Prasodjo, 2017). The tourism sector is growing so rapidly that the government projects that the tourism sector will become the largest foreign exchange contributor by 2020 . Not a too grandiose target. Because Indonesia has a thousand and one tourist destinations, both those that have been exposed and those that are still hidden. Supported also by infrastructure development that continues to be encouraged, the world of tourism is certain to be a new prima donna for State revenue (Boes et al., 2016; Nuryanti, 1996; O'Riordan et al., 1983; Ye et al., 2011). Tourism is a sector that plays an important role in efforts to increase income (Cohen et al., 2014; Higgins-Desbiolles et al., 2019; Wilkinson, 2001). Indonesia is a country that has natural beauty and cultural diversity, so it is necessary to increase the tourism sector. This is because tourism is a sector that is considered profitable and has the potential to be developed as an asset that is used as a source of income for the Nation and State.

Tourism Service Business which is regulated in Law no. 9 of 2010, namely tourist attractions, tourism areas, tourism transportation services, tourism travel services, food and drink services, accommodation provision, organizing entertainment and recreation activities, organizing meetings, incentive trips, conferences and exhibitions, tourism information services, 
tourism consulting services, tour guides, water tours, and spas. Of the various types of service businesses, it cannot be denied that all of them need each other and are related to the progress of tourism. Also, from the reasoning regarding the 13 service businesses, it can be concluded that tourism itself is an activity in which it is not only for recreation, vacation, or just leisure time but also for doing business, for example in activities in the MICE sector.

MICE is one of the tourism activities whose activities are a combination of leisure and business, usually involving a group of people together, a series of activities in the form of meetings, Incentive travels, Conventions, Congresses, Conferences and Exhibition (MICE, 2015). The MICE industry is an indicator of the economic development of a country where every event at the national and international level requires hardware support in the form of physical infrastructure and software which includes the support of competent human resources and has excellent service mentality.

The potential of the MICE industry in South Sulawesi Province has very good prospects going forward. As a transit area in Eastern Indonesia, South Sulawesi has several excellent infrastructure and tourist areas. In 2015, the MICE industry sector has made the largest contribution to the economy of South Sulawesi and its trend shows a significant increase every year. Various regions in South Sulawesi have prepared themselves to enter and are ready to become one of the cities that organize MICE in Indonesia. One of them is the City of Makassar, which almost throughout the year various activities are held, both in the implementation of MICE from the local government segment, as well as from national and international markets. This condition is also supported by the provision of MICE facilities in South Sulawesi which are the most present in eastern Indonesia and can accommodate participants on a large scale. The addition of the number of international standard hotels and the availability of rooms is one of the keys, that this province has positioned itself as an area for the development of the MICE industry in Kawan Timur Indonesia. The event activity in South Sulawesi is an activity that is often carried out every year. The event was held by various event organizers from the City District who came from South Sulawesi.

The Meeting Industry or better known as MICE stands for Meeting, Incentive Travel, Conference, and Exhibitions. According to the World Tourism Organization, these meetings and business events are tourism activities that make a significant contribution to the Gross Domestic Product of a country and region and can become branding for a destination (UNWTO, 2016).

The importance of targeting business visitors / MICE as stated by Taleb Rifai (SecretaryGeneral of UNWTO): "In addition to important business opportunities, the Meetings Industry provides immense benefits to the broader economy as it generates on average a higher spending level, reduces seasonality, contributes to the regeneration of destinations, spreads knowledge and enhances innovation and creativity "(UNWTO, 2014). Apart from spending more visitors, being able to cover the low season, contributing to updating destinations, spreading knowledge, and increasing innovation and creativity. As a comparison, the expenditure of business visitors / MICE in Thailand is 3.5 times that of leisure visitors (Khaul in Setyawan, 2018).

\section{METHOD}

The approach used in this research is descriptive qualitative in which this research was conducted in South Sulawesi, especially in the areas of Makassar, Parepare, and Toraja. As for the informants in this study, namely the Government through the Department of Culture and 
Tourism of South Sulawesi Province, Mistrianie FA Muin (Owner Senada Project), Sriyanti Mandong (Debindo Marketing Manager), Safri Sayuti (Yellow Project), and Burhanuddin (Owner CV. Smart Media). The data required in this study were collected through several techniques. The techniques used were observation, interviews, and documentation. Data that has been obtained through observation, interviews, and documentation (books, newspapers, social media, and the internet) will be processed and analyzed. This is done to simplify the data and complete the required data so that the objectives of this research can be achieved. This research will display information through exposure, depiction, and tell the actual situation of the object under study based on existing facts. The data that has been collected is then classified according to the focus of the research to answer the problem formulation, then the data will be analyzed with theories related to the object of research.

\section{RESULT AND DISCUSSION}

Human resources are an important component for an organization or company. Human resources occupy a strategic position in an organization, therefore human resources must be mobilized effectively and efficiently so that they have a high level of yield. HR management is a series of strategies, processes, and activities designed to support company goals by integrating the needs of the company and its individuals (Rivai \& Sagala, 2009). Therefore the quality of human resources plays an important role in every sector.

The development of the tourism sector is influenced by the quality of human resources. The importance of human resources in the tourism sector is a very important resource in most organizations. Particularly in service-based organizations, HR plays a key role in achieving successful performance (Evans et al., 2012). The human quality factor is a key success factor and plays an important role in the achievement of an industry. This also affects the tourism industry, because this industry has a direct, intangible relationship with consumers who depend on the quality of employee human resources to create pleasure and interest, and comfort to consumers. The ability of employees is very influential on the level of customer satisfaction. So that every effort to provide the best service because it relates to company revenue.

Based on the results of the interview, the resource person explained the important role of human resources possessed by the Event Organizer which greatly affects the level of customer satisfaction. So that EOs who work in the field of service provision is highly dependent on the services provided by their employees. This was also stated by Nandi (2008) that the product of the tourism industry is a service, therefore the emphasis must be on the aspect of service that is tailored to the needs of tourists. In the tourism industry, service quality is the main indicator that shows the level of professionalism.

The existence of a professional event organizer can help develop MICE as an industry multiplier effect. Based on the Regulation of the Minister of Tourism of the Republic of Indonesia Number 5 of 2017, the criteria for the Professionalism of Human Resources (HR) MICE Destinations are having MICE HR who have competitive value and gain recognition of national and international competencies. Readiness can be seen from the existence of PCO, PEO, DMC, EO, and other supporters such as MICE educational institutions. One of the indicators that must be met is that the destination must be equipped with a licensed professional service company specifically for carrying out events.

South Sulawesi as a MICE tourist destination has many event organizers. The existence of EO is a form of South Sulawesi's readiness as a MICE tourist destination or convention. 
Some of these EOs have held several large and even national events held in South Sulawesi and even outside the Province.

Based on the interview, it was found that the EO's experience in South Sulawesi was quite good. However, only a few Human Resources who work at the EO have education with a MICE background. Whereas tourism education is one of the keys to developing tourism potential (tourist areas) because this field requires skilled labor which must be continuously developed. According to Spillane James. J (1994): "One of the problems in developing tourism is the unavailability of sufficient facilities to support tourism education. A capable, skilled, highly skilled workforce and dedication in their field (professional) are an absolute necessity in competing in the global market. The product of the tourism industry is a "service", therefore the emphasis must be on the aspect of services tailored to the needs of tourists. In the tourism industry, service quality is the main indicator that shows the level of professionalism.

The results of the interview show that EOs still rely on the on-the-job learning system for human resources who do not have a MICE educational background. This is following the statement from Kesrul (2004) that the quality of the workforce is low because restaurant entrepreneurs generally impose learning by doing system, low promotional budgets for souvenir shops, event organizers do not have a professional conference (meeting) organizer certificate which is legality for businesses. they, attractions on tourist objects are rarely carried out and accessibility to marine tourism objects from the meeting hall or hotel where the participants stay has not been adjusted to the characteristics of MICE tourists, namely the time they have is very limited. Because it can be said that not all human resources owned by EOs have professional certificates but have good enough experience.

The event organizer in South Sulawesi already has several employees who have certificates of expertise. The certificate is useful as proof that the EO has expertise in MICE tourism. Also, the certificate of expertise functions as a complement to EO documents to participate in the auction/procurement of MICE held by the government and to convince consumers to use the EO services. This was also conveyed by Zairil (2020) that MICE certification is needed because it will provide competitive value and gain competency recognition, both at the National and International Levels.

Based on the results of interviews, MICE tourism actors are constrained in fulfilling human resources who have certificates of expertise in the MICE field. This situation is due to the lack of a specialized MICE certification body. MICE industry players in South Sulawesi must send their employees to Jakarta to collect the expertise certificate. This problem is the main obstacle for EOs in South Sulawesi to have certified quality human resources.

The existence of a certification body in the field of MICE tourism is one of the major obstacles in South Sulawesi and even in Indonesia. Based on data from the National Accreditation Committee in 2019 there are 37 Tourism Certification Bodies, but there is only 1 (one) certification body that specializes in MICE accreditation located in Jakarta. This is an obstacle that must be addressed by the Government in providing competent human resources. (Zairil, 2020).

\section{Discussion}

Organizational HR development is one form of an organization's strategy to get quality HR. (Sedarmayanti, 2018) which states that the purpose of training and development is to improve the level of effectiveness of employee performance in achieving the results set by the 
company. Thus, in general, the purpose of employee training and development is to increase knowledge, increase skills and change attitudes. Therefore a strategy is needed to improve the EO HR in Susel.

In general, education, training, and career development are strategies used by event organizers in South Sulawesi in human resource development. This was also stated by Francisco Sofo that improving the quality of Human Resources through training, education, and development programs so that it can explain developmental practices and requires collaboration with Human Resource Management programs to achieve the desired results. Also, there is an event organizer HR development strategy besides using the three strategies, namely the apprenticeship strategy and. This strategy is used to improve the competence and skills of workers who do not have a MICE educational background and to get human resources who have high loyalty and a great work spirit.

Researchers found that the implementation of HR development strategies in the South Sulawesi Event Organizer is in line with the HR development theory of Robert L. Mathius and John H. Jackson, who argue that teacher development in educational institutions can be effectively implemented through strategies, namely: (a) Creating design planning for development needs, (b) Creating a development program, (c) Implementing a development program, and (d) Evaluating development. The EO adopts these strategies and summarizes them in 3 stages, namely the initial stage, the implementation stage, and the evaluation stage.

In general, activities at the initial stage/event organizer planning are activities included in the human resource planning step according to Robert Mathius and Jakson (2001), namely conducting human resource planning starting by considering organizational goals and strategies; Perform needs analysis in the internal and external environment. Environmental analysis is a process of researching an organizational environment to determine opportunities and threats. Human resource development planning at EO in South Sulawesi is almost the same as this step. In making HR development planning designs, the Event Organizer does the following 3 things: setting HR development goals, Analyzing development needs, and Conducting Focus Group Discussions (FGD)

The application of in detail the formal and non-formal education development patterns used as an EO HR development strategy in South Sulawesi is called integrated education. According to Setiawan (2016) tourism education is one of the keys to developing tourism potential (tourist areas), because this field requires skilled labor which must be continuously developed.

Human resource development in EO can be seen from the 3 main strategies taken, namely development through apprenticeship (understudy) and guidance (coaching), development through education and training, and career development. the apprenticeship and coaching strategies are one of the strategies used by EOs to forge employees / HR. This is done as a solution to the lack of human resources with a professional background in tourism, especially MICE tourism. One of the obstacles that will be faced in developing tourism

The objective of the strategy for developing professional skills is to increase the competence of human resources, which is carried out to meet the needs of the human resources concerned or the capabilities required by the institution concerned. The development of the field of professional ability is carried out utilizing education and training, namely by taking further studies to a higher level, participating in training, seminars, workshops, and some activities that can improve abilities. 


\section{Jurnal Administrare: Jurnal Pemikiran Ilmiah dan Pendidikan Administrasi Perkantoran \\ Volume 8 Issue 1, January-June 2021. Pages 69-76}

The HR career development strategy at EO is one way to produce loyal and quality human resources. Since the beginning of EO HR recruitment, an apprenticeship and coaching system was first carried out to assess an employee's worthiness. As stated in the Regulation of the Minister of Tourism of the Republic of Indonesia Number 5 of 2017, concerning the Criteria for Professional Human Resources (HR) MICE that the main factor that must be possessed by EOs is competitive HR.

Career development in EO is carried out in three ways, namely by recruitment, promotion, and transfer. This approach is following that stated by (Alwi, 2011) (that in the perspective of Human Resource Management there are two approaches/strategies, namely; a) buy approach, which is an approach that is oriented towards human resource withdrawal, and b) approach, namely, development-oriented towards developing existing human resources in the form of training, education, and guidance.

The career development strategy carried out by EO is generally following the theory put forward by (Zainal, 2015) which states that in developing a career, each individual plays an important role in increasing his / her potential. Because besides, to improve the quality and image, the subject of career development itself is each individual.

The form of individual career development is shown, among others, by satisfactory achievement and loyalty to the organization. Responsibility and honesty, as well as long service life, are forms of loyalty to the organization. This is used as an indicator in the HR development process so that promotions or transfers are carried out after seeing the results of their performance.

The evaluation process of the Human Resources Development Program at EO in South Sulawesi is carried out through performance supervision. The stage function is to control the process and results of the development program to guarantee a systematic, effective and efficient program.

In its implementation, the event organizer measures the results of the HR development program against the standards required by organizations in the MICE industry. This is to see the effectiveness and efficiency of the program. From these results, it will be decided which programs will be continued, and which will be terminated. Assessment of performance is carried out by assessing changes in employees / HR before and after participating in the development program. This is in line with the training evaluation model developed for the first time by (Kirkpatrick \& Kirkpatrick, 2008) by using the four levels in categorizing training results. Based on the points in general outline the EO conducts training and development evaluations comparing the results after training to the goals expected by the company. To produce capable of producing skilled and reliable human resources in the field of MICE tourism.

\section{CONCLUSION}

The quality of MICE Human Resources at the Event Organizer in South Sulawesi Selatan can be said to be quite good. Although only a few EOs have human resources with MICE educational backgrounds. However, some of the human resources owned by EO have certificates of expertise and experience in conducting regional and national-scale events. MICE Human Resource Development Strategy in increasing the competitiveness of the Organize Event in South Sulawesi, namely 3 main strategies, namely development through internships 
(understudy) and guidance (coaching), development through education and training, and career development.

\section{REFERENCES}

Alwi, S. (2011). Manajemen Sumber Daya Manusia Strategi Keunggulan Kompetitif. BPFE UGM, Yogyakarta.

Boes, K., Buhalis, D., \& Inversini, A. (2016). Smart tourism destinations: ecosystems for tourism destination competitiveness. International Journal of Tourism Cities. https://doi.org/10.1108/IJTC-12-2015-0032

Cohen, S. A., Prayag, G., \& Moital, M. (2014). Consumer behavior in tourism: Concepts, influences and opportunities. In Current Issues in Tourism. https://doi.org/10.1080/13683500.2013.850064

Evans, N., Campbell, D., \& Stonehouse, G. (2012). Strategic management for travel and tourism. In Strategic Management for Travel and Tourism. https://doi.org/10.4324/9780080498294

Hasyim, D., Gunawan, A., Sudi, M., Mustafa, D., \& Rijal, R. (2020). The Government's Role in the Development of Yendi Beach Tourism Destinations in Biak Numfor Regency. Jurnal Ad'ministrare, 6(2), 186-189.

Higgins-Desbiolles, F., Carnicelli, S., Krolikowski, C., Wijesinghe, G., \& Boluk, K. (2019). Degrowing tourism: rethinking tourism. Journal of Sustainable Tourism. https://doi.org/10.1080/09669582.2019.1601732

Kadji, J. (2015). Optimalisasi Tata Kelola Sektor Pariwisata di Kabupaten Gorontalo. Jurnal Ad'ministrare: Jurnal Pemikiran Ilmiah Dan Pendidikan Administrasi Perkantoran, 2(1), $1-15$.

Kirkpatrick, D. L., \& Kirkpatrick, J. D. (2008). Evaluating Training Programs: The Four Levels. In Evaluating Training Programs.

MICE. (2015). Meetings, Incentives, Conventions and Exhibitions (MICE). Journal of Convention and Event Tourism.

Muhtasom, A., \& Ab, A. (2019). Kahayya Village as a Priority Destination for Rural Tourism Development Policy in Bulukumba Regency. Jurnal Ad'ministrare, 6(1), 1-8.

Nuryanti, W. (1996). Heritage and postmodern tourism. Annals of Tourism Research. https://doi.org/10.1016/0160-7383(95)00062-3

O’Riordan, T., Mathieson, A., \& Wall, G. (1983). Tourism: Economic, Physical and Social Impacts. The Geographical Journal. https://doi.org/10.2307/634029

Prasodjo, T. (2017). Pengembangan Pariwisata Budaya dalam Perspektif Pelayanan Publik. Jurnal Office, 3(1), 7-12.

Sedarmayanti. (2018). Tata Kerja dan Produktivitas Kerja. In Bandung, CV Mandar Maju.

Wilkinson, P. F. (2001). Information and Communication Technologies in Tourism. Annals of 
76 | Jurnal Administrare: Jurnal Pemikiran Ilmiah dan Pendidikan Administrasi Perkantoran Volume 8 Issue 1, January-June 2021. Pages 69-76

Tourism Research. https://doi.org/10.1016/s0160-7383(01)00012-3

Winowatan, W. J. (2019). Persepsi Stakeholder terhadap Kurikulum Berbasis Kompetensi Politeknik Pariwisata Makassar (Studi pada Industri Perhotelan Kota Makassar). Jurnal Ad'ministrare, 5(2), 123-128.

Ye, Q., Law, R., Gu, B., \& Chen, W. (2011). The influence of user-generated content on traveler behavior: An empirical investigation on the effects of e-word-of-mouth to hotel online bookings. Computers in Human Behavior. https://doi.org/10.1016/j.chb.2010.04.014

Zainal, V. R. (2015). Manajemen Sumber Daya Manusia. Manajemen Sumber Daya Manusia Untuk Perusahaan Dari Teori Ke Praktik. 